\title{
PELATIHAN MINDFUL PARENTING BAGI IBU DENGAN BALITA DI CEMPAKA PUTIH
}

\author{
Zulfa Febriani $^{1)}$, Dewi Kumalasari ${ }^{2}$, Arif Triman $^{3)}$, Endang Fourianalistyawati ${ }^{4)}$ \\ ${ }^{1,2,3,4)}$ Fakultas Psikologi universitas YARSI, Jakarta Pusat \\ E-mail: zulfa.edu@gmail.com
}

\begin{abstract}
Abstrak
Semakin banyak jumlah anak-anak yang mengalami masalah sosial perlu menjadi perhatian bukan hanya keluarga anak yang mengalami masalah tersebut namun juga masyarakat dan sistem sosial yang ada di lingkungan anak-anak tersebut tumbuh dan berkembang. Pelatihan ini merupakan salah satu wujud kepedulian yang ditujukan untuk para ibu dengan anak usia balita dalam pengasuhannya. Masa lima tahun pertama merupakan masa pengasuhan yang penting bagi tumbuh kembang anak secara fisik, kompetensi intelektual, maupun kecakapan dalam perilaku interpersonal dan tatanan sosial masyarakat. Pengasuhan yang baik adalah bagaimana orang tua terlibat dan merespon kebutuhan anak. Hal ini dapat dicapai dengan melakukan mindful parenting yang mencakup bagaimana orang tua mendengarkan dengan penuh perhatian, menerima keadaan diri dan anak tanpa penghakiman, menyadari keadaan emosi diri dan anak, regulasi diri dan berwelas kasih dalam proses pengasuhan. Oleh karena itu, pelatihan ini diberikan dengan tujuan untuk menambah pengetahuan dan keterampilan ibu yang memiliki balita dalam melakukan pengasuhan secara mindful parenting. Peserta adalah para ibu yang mengikuti kelas balita di Puskesmas Kecamatan Cempaka Putih Jakarta Pusat. Berdasarkan informasi yang didapat, ada kebutuhan dari peserta yang memiliki bayi usia 1-2 tahun mengenai bagaimana cara menghadapi anak dengan permasalahan seperti tantrum, susah makan, dan sebagainya. Pelatihan dilakukan dengan model ceramah, diskusi, dan latihan terkait materi mindful parenting. Sebanyak 27 peserta hadir dengan membawa anak-anak mereka. Hasil pelatihan menunjukkan adanya peningkatan pengetahuan mengenai mindful parenting dan kemapuan melakukan teknik mindful parenting. Secara keseluruhan, peserta merasa puas dan mendapatkan manfaat dari pelatihan yang diberikan
\end{abstract}

Kata Kunci: psikoedukasi pengasuhan, mindful parenting, ibu dengan anak balita

\section{PENDAHULUAN}

Kementrian Sosial menyatakan bahwa anakanak yang mengalami masalah meningkat tiap tahun. Tanggungjawab perilaku tumbuh kembang anak utamanya berada pada keluarga dan keluarga besarnya sementara pemerintah membantu dari sisi perundang-undangan dan lembaga-lembaga terkait seperti BKKBN, Kemendikbud, Kemensos, dan Kemenag. Seto Mulyadi, pemerhati masalah anak, menambahkan bahwa perlindungan anak tidak bisa hanya dilakukan oleh keluarga, namun masyarakat memiliki peran yang sama dalam memberikan perlindungan terhadap tumbuh kembang anak (Setyawan, 2015). Oleh karena itu, sebagai salah satu wujud kepedulian dan promosi kesehatan keluarga, penulis mengusung tema kegiatan pengasuhan.

Pengasuhan yang negatif dapat mengakibatkan berbagai masalah perilaku anak, bahkan juga mengganggu tumbuh kembangnya secara fisiologis. Hal ini dapat terjadi sejak awal 5 tahun pertama tumbuh kembang anak karena pengasuhan pada periode ini memberikan dasar perkembangan sensori motorik anak, kemampuan bahasa, kognitif, konsep diri dan harga diri anak, kemampuan regulasi diri, dan keterampilan sosial (Harvard Family Research Project, 2006; Bower \& Casas, 2016).

Hasil penelitian menunjukkan bahwa ibu yang memiliki sensitivitas dan responsivitas yang baik ketika anak berusia enam dan sembilan bulan memprediksi level resiliensi ego yang lebih tinggi saat anak berusia tujuh tahun, yaitu kemampuan beradaptasi terhadap perubahan atau suasana yang penuh tekanan, merubah perilaku yang dibutuhkan, dan memecahkan masalah dengan fleksibel. Sementara, pengasuhan yang kaku dan buruk berkaitan dengan rendahnya resiliensi ego selama masa anak-anak (Taylor, Einsenberg, Spinrad \& Widaman, dalam Taylor dkk., 2014). Penelitian lain menunjukkan bahwa Ibu yang memiliki masalah psikologis biasanya memiliki level sensitivitas, responsivitas, keterlibatan yang rendah dalam interaksinya dengan anak, juga menunjukkan lebih banyak ekspresi emosi yang negatif dan perilaku buruk (Dix \& Meunier dalam Ciciolla, Gerstein, \& Crnic, 2014). Masalah psikologis ibu seringkali dianggap sebagai kunci faktor resiko dalam perkembangan masalah perilaku anak (Cummings \& 
Davies, dalam Ciciolla dkk., 2014), seperti kesulitan dalam meregulasi emosi, mengontrol perilaku dan impuls dan seringkali melanggar aturan (Goodman \& Gotlib; Louma dkk.; Zahn-Waxler, Iannotti, Cummings \& Denham; Kuczynski \& Kochanskam, dalam Ciciolla dkk., 2014).

Coatsworth dkk.(2015) mengatakan bahwa mengajarkan teknik mindfulness kepada para orang tua atau pengasuh dapat membantu orang tua melakukan pengasuhan yang lebih efektif. Mindfulness menurut McCaffrey, Reitman, dan Black (2017) mengacu pada konsep yang dijelaskan Kabat-Zinn, yaitu memberikan perhatian secara tertentu, dengan tujuan tertentu, berfokus pada waktu yang sedang berlangsung, dan tanpa penghakiman. Konsep ini diterapkan pada pengasuhan dengan istilah mindful parenting yang menurut Kabat-Zinn adalah memberikan perhatian kepada anak dan cara pengasuhan secara tertentu, dengan kesungguhan, pada saat berlangsung, dan tanpa penghakiman. Menurut Duncan, Coatsworth, dan Greenberg, (2009), mindful parenting terdiri atas lima dimensi yaitu mendengarkan dengan penuh perhatian, menerima keadaan diri dan anak tanpa penghakiman, menyadari keadaan emosi diri dan anak, regulasi diri dan berwelas kasih dalam interaksi pengasuhan. Mindful parenting dapat ditingkatkan melalui latihan dan intervensi.

Hasil-hasil penelitian menunjukkan bahwa orang tua, khususnya ibu yang mengikuti pelatihan mindful parenting ini dapat menurunkan reaktivitas orang tua dan meningkatkan kesabaran dalam menghadapi anak, meningkatkan fleksibilitas dalam pengasuhan, responsivitas, konsistensi, dan iklim pengasuhan yang sesuai dengan nilai dan tujuan pengasuhan, memilih strategi pengasuhan yang lebih efektif, meningkatkan hubungan orang tua-anak dengan memperbaiki rasa kepercayaan dan berbagi emosi yang baik, menurunkan stres pengasuhan (Dumas; Dishion dkk., dalam McCaffrey dkk., 2017; Duncan \& Bardacke, 2010), juga berdampak pada pengurangan resiko masalah pada anak (Duncan et al., 2009), meregulasi kemarahan dan mood negatif, keberfungsian keluarga dan strategi kedisiplinan (Coatsworth dkk.; Singh dkk.; Van der Oard dkk.; Dawe \& Harnett; dalam Coatsworth dkk., 2015). Studi kasus menunjukkan bahwa mereka yang mengikuti latihan mindfulness di California, Colorado, dan Georgia menyadari perbedaan besar dalam kemampuannya untuk memberikan fokus perhatian kepada bayi (Snyder, Shapiro, \& Treleaven, 2012) dan meningkatkan kepuasan dalam pengasuhan (Singh, dkk. dalam Duncan \& Bardacke,
2010). Jika ayah atau ibu terfokus pada perhatian dirinya sendiri, mereka tidak akan dapat memperhatikan sinyal yang bayi ingin jalin yang dapat menjadi dasar pola kelekatan yang aman dan perkembangan kognisi di kemudian hari (Murray; Murray \& Cooper; dalam Hughes dkk., 2009).

Menjadi ayah-ibu dan mengasuh anak merupakan rangkaian tugas perkembangan seseorang yang telah menikah dan memiliki anak. Berdasarkan penelitian yang telah dipaparkan, peran sebagai model dan menciptakan suasana interaksi yang positif bagi anak sangat penting dimiliki oleh setiap orang tua. Proses ini merupakan proses adaptasi yang berkelanjutan yang sehari-hari dihadapi orang tua. Meskipun demikian, proses sehari-hari ini dapat menjadi tekanan yang cukup kompleks. Sebagaimana dinyatakan oleh Crnic dan Low (2002) bahwa perilaku anak-anak dan rutinitas pengasuhan dapat membingungkan, mengecewakan, atau membuat marah sehingga menjadi sumber stres tertentu bagi orang tua dan mempengaruhi hubungan pernikahan, terutama mereka yang baru memiliki anak hingga tiga tahun pertama setelah anak lahir. Hal ini juga dinyatakan oleh Cooklin, Giallo, dan Rose (2012) bahwa perilaku anak dan aktivitas pengasuhan sehari-hari dapat mengakibatkan kelelahan pada orang tua terutama ketika anak masih bayi hingga anak usia dini (pra sekolah) yang berdampak pada keberfungsian psikologis orang tua hingga memunculkan perilaku pengasuhan yang kurang optimal.

Sayangnya, tidak ada lembaga pendidikan formal yang mengajarkan bagaimana menjadi orang tua yang baik. Kelas parenting yang membahas mengenai bagaimana peran orang tua terhadap anak dan pengasuhan yang baik sudah banyak diadakan di Jakarta. Pihak pelaksana antara lain lembaga sosial, pengajian, lembaga pendidikan anak usia dini, lembaga pemerintahan, dan sebagainya. Lembagalembaga ini belum tentu dapat dicapai oleh setiap orang tua sehingga perlu upaya pendekatan dari para ilmuwan dan praktisi untuk menjangkau orang tua melalui komunitas-komunitas yang ada di sekitarnya. Mindful parenting juga merupakan topik dan metode yang cukup baru di Indonesia dan belum banyak diteliti dan diterapkan. Maka penulis berupaya mengadakan pelatihan mindful parenting yang targetnya adalah memberikan pengetahuan tentang apa saja yang menjadi tantangan orang tua, dari mana saja sumber tantangan tersebut, serta bagaimana upaya yang dapat dilakukan oleh orang tua. Hal yang paling penting adalah mengajarkan secara langsung bagaimana membangun relasi 
emosional yang positif dengan anak melalui mindfulness dalam pengasuhan (mindful parenting), yaitu memberikan perhatian dalam interaksi dengan anak secara fokus, tidak reaktif, dan tidak menghakimi diri sendiri ataupun anak.

Penulis mendapatkan informasi dari pengelola Puskesmas Kecamatan Cempaka Putih Jakarta Pusat bahwa salah satu layanan puskesmas ini adalah kelas balita untuk orang tua yang diadakan secara rutin. Menurut pengelola layanan, beberapa pertanyaan yang sering muncul adalah terkait pengasuhan seperti menghadapi pola emosi anak, anak sulit makan, dan sebagainya. Hal ini merupakan persoalan hari-hari yang menjadi tantangan pengasuhan sebagaimana yang telah dijelaskan. Dengan demikian, penulis memberikan psikoedukasi dan pelatihan mindful parenting untuk para ibu yang mengikuti kelas balita tersebut. Kegiatan ini diharapkan menambah pengetahuan dan keterampilan para ibu dengan anak balita tentang mindful parenting.

\section{METODE KEGIATAN}

Peserta pelatihan ini adalah 27 orang ibu yang memiliki balita dan mengikuti kegiatan kelas balita di Puskesmas Cempaka Putih. Narasumber dan pelaksana terdiri dari empat orang dosen Fakultas Psikologi YARSI yaitu Zulfa Febriani, M.Psi., Psikolog, Endang Fourianalistyawati, M.Psi., Psikolog., Dewi Kumalasari, M.Psi., Psikolog, dan Arif Triman, M.Ed. serta empat orang mahasiswa Psikologi YARSI sebagai asisten, yaitu Widya Saraswati, Nur Zuhriyah A. Kasuba, Najmi Afifa Alkatiri, dan Cindi Anggraini.

Pelatihan ini dilakukan dalam dua sesi. Sesi pertama diisi dengan model ceramah dan diskusi mengenai pengasuhan selama 75 menit. Sesi kedua diisi dengan pengenalan mindful parenting dan cara melakukannya selama 60 menit.

Pada sesi pertama, penulis menjelaskan tentang pengasuhan sambil melibatkan partisipan berdialog mengenai hal-hal yang sering dianggap sebagai tantangan-tantangan dalam pengasuhan dan dari mana saja sumber tantangan itu berasal. Penulis juga mengenalkan istilah stres pengasuhan yang merupakan ketegangan atau kecemasan yang dialami orang tua dalam interaksinya sehari-hari dengan anak. Penulis menjelaskan bahwa stres pengasuhan merupakan hal yang wajar namun bisa dikelola. Peserta diberitahu mengenai bagaimana mengelola stres harus disadari dan diawali dengan penerimaan tulus terhadap kondisi yang ada, baik di diri atau pun

anak, sehingga memungkinkan orang tua untuk membuka sudut pandang yang lebih positif. Peserta juga dihimbau untuk bekerja sama dan berbagi peran yang lebih fleksibel dengan pasangan serta mempelajari ilmu atau keterampilan mengasuh anak.

Sesi dua, penulis menjelaskan bahwa dengan menyadari kondisi dan interaksi dalam mengasuh anak, orang tua pada dasarnya mempraktikkan mindful parenting. Penulis menjelaskan bahwa mindful parenting merupakan kemampuan seseorang dalam memusatkan perhatian pada interaksi dengan anak yang saat ini sedang berlangsung, mendengarkan sepenuh hati, mengelola diri dan emosi, tidak menghakimi dan welas asih kepada diri sendiri dan anak. Penekanannya adalah pada keadaan menyadari bahwa orang tua sedang melakukan kegiatan pengasuhan, ada tujuan yang ingin dicapai, dan apa yang dilakukan terarah pada tujuan tersebut. Penulis membimbing peserta melakukan teknik mindfulness saat berinteraksi dengan anak. Penulis mengajarkan keterampilan mengenali sinyal-sinyal stres dari sensasi tubuh yang muncul, pikiran dan perasaan yang muncul, dan kecenderungan perilaku. Penulis mengajarkan teknik untuk memberi jeda ketika ada kejadian dalam interaksi dengan anak yang menyulut emosi, latihan mengelola nafas dan mengenali sensasi, pikiran, dan perasaan yang muncul, kemudian memilih respon yang tepat.

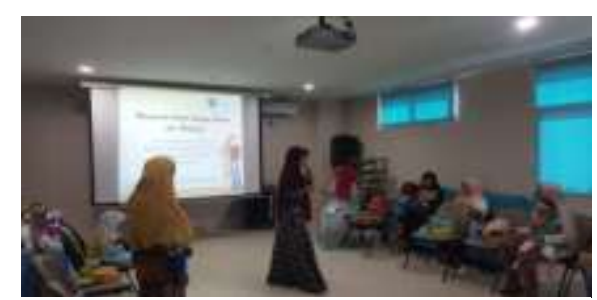

Gambar 1. Sesi satu (kiri) dan sesi

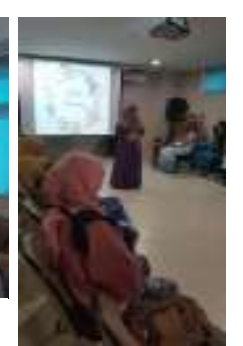

Pengukuran terhadap efektivitas pelatihan dilakukan dengan memberikan kuesioner pre-test dan post-test yang memuat soal tentang mindful parenting. Pre-test dan post-test juga memuat kuesioner Mindful Attention Awareness ScaleMAAS yang dikembangkan oleh Brown dan Ryan dan mengukur keterbukaan atau penerimaan atas kesadaran peristiwa saat ini. MAAS terdiri atas 15 aitem dengan nilai rentang skala 1 hingga 6 . Semakin tinggi skor pada skala ini menunjukkan keadaan yang tidak menerima atau menyadari peristiwa yang dihadapi (mindless state), semakin rendah skor menunjukkan semakin menerima dan menyadari peristiwa saat ini (mindfulness) (Brown, A. P., Marquis, A., \& Guiffrida, 2013). 
Data dianalisis dengan menggunakan teknik statistik deskriptif untuk mengetahui gambaran skor pengetahuan dan kemampuan peserta mengenai mindful parenting baik sebelum pelatihan dimulai maupun setelah mendapatkan pelatihan. Untuk mengetahui efektivitas pelatihan, penulis melakukan uji beda dengan teknik analisis Wilcoxon karena jumlah peserta yang mengisi kuesioner di bawah 30 .

Selain pengukuran aspek kognitif dan keterampilan, penulis juga melakukan evaluasi terhadap kegiatan pelatihan yang dilaksanakan untuk mendapatkan umpan balik dari peserta. Peserta diminta mengisi kuesioner kepuasan kegiatan pada akhir sesi pelatihan. Aspek yang dinilai adalah kejelasan materi, sikap fasilitator, metode kegiatan, manfaat kegiatan, sarana dan fasilitas serta konsumsi yang disediakan. Penilaian berkisar dari rentang tidak memuaskan hingga sangat memuaskan.

\section{HASIL DAN PEMBAHASAN}

Pengetahuan partisipan mengenai mindful parenting diukur dengan kuesioner yang menanyakan pengertian mindful parenting sebelum kegiatan dimulai dan setelahnya. Hasil perhitungan statistik menunjukkan adanya peningkatan skor sebesar 2,7 poin setelah peserta mendapatkan penjelasan mengenai materi. Peningkatan skor dapat dilihat pada tabel 1. Meskipun terjadi peningkatan skor, uji statistik Wilcoxon menunjukkan bahwa perbedaan skor sebelum dan sesudah pelatihan ini tidak signifikan dengan $\mathrm{Z}=1,683, \mathrm{p}=, 101$.

Kemampuan mindfulness peserta pelatihan sebelum dan sesudah mendapatkan pelatihan ditunjukkan melalui penurunan nilai MAAS. Skor rata-rata MAAS peserta sebelum pelatihan adalah 94,36 dan setelah pelatihan adalah 64,44 (tabel 2). Uji beda dengan teknik analisis Wilcoxon menunjukkan penurunan nilai tersebut signifikan $(\mathrm{p}<$ ,05) (tabel 3). Hal ini menunjukkan bahwa setelah mendapatkan pelatihan mindful parenting, peserta mengalami peningkatan kemampuan mindfulness.

Tabel 1. Hasil pre-post test pengetahuan mindful parenting

\begin{tabular}{lccccc}
\hline & $\mathrm{N}$ & $\begin{array}{c}\text { Mini } \\
\text { mum }\end{array}$ & $\begin{array}{c}\text { Maxi } \\
\text { mum }\end{array}$ & Mean & $\begin{array}{c}\text { Std. } \\
\text { Dev. }\end{array}$ \\
\hline Pretest & 22 & .00 & 8.00 & 2.9 & 2.79 \\
Posttest & 13 & 1.00 & 9.00 & 5.69 & 1.97 \\
$\begin{array}{l}\text { Valid N } \\
\text { (listwise) }\end{array}$ & 13 & & & & \\
\hline
\end{tabular}

Tabel 2. Hasil pre-post test keterampilan mindfulness

\begin{tabular}{lccccc}
\hline Variable & $\mathrm{N}$ & $\begin{array}{c}\text { Mini } \\
\text { mum }\end{array}$ & $\begin{array}{c}\text { Maxim } \\
\text { um }\end{array}$ & Mean & $\begin{array}{c}\text { Std. } \\
\text { Dev. }\end{array}$ \\
\hline $\begin{array}{l}\text { Pretest } \\
\text { MAAS }\end{array}$ & 22 & 73 & 162 & 94,36 & 18,45 \\
$\begin{array}{l}\text { Posttest } \\
\text { MAAS }\end{array}$ & 18 & 52 & 79 & 64,44 & 9,28 \\
\hline
\end{tabular}

Tabel 3. Uji beda pre-post test keterampilan mindfulness

\begin{tabular}{cccc}
\hline Null Hypothesis & Test & Z & Sig \\
\hline Perbedaan median & Related & $-3,73$ &, 000 \\
antara pretest dan & Samples & & \\
posttest mindfulness & Wilcoxon & & \\
adalah 0 & Signed Rank & & \\
& Tets & & \\
\hline
\end{tabular}

Psikoedukasi dan pelatihan mindful parenting secara umum dapat meningkatkan pengetahuan peserta mengenai mindful parenting serta menambah keterampilan mindfulness peserta ketika berinteraksi dengan anak. Hal ini dapat diketahui dari peningkatan skor pengetahuan peserta mengenai mindful parenting pada akhir sesi kegiatan meskipun tidak signifikan. Peningkatan skor tidak signifikan diperkirakan terjadi karena jumlah peserta yang mengisi pre dan post test tidak sama. Jumlah peserta yang tercatat pada daftar kehadiran adalah sebanyak 27 orang. Sementara peserta yang mengisi pretest sebanyak 22 orang dan mengisi posttest sebanyak 13 orang. Artinya terdapat penyusutan jumlah peserta yang mengisi kuesioner posttest.

Perbedaan jumlah peserta yang mengisi pretest dan posttest ini disebabkan oleh kendala situasional. Pretest diberikan sebelum kegiatan dimulai yang mana saat itu peserta belum hadir secara lengkap padahal waktu sudah lewat dari jadwal yang ditentukan. Informasi mengenai jadwal kegiatan sudah disampaikan melalui Whatsapp Grup kelas Balita Puskesmas namun mungkin karena para ibu biasanya memulai kelas balita pada jam 9.00 sehingga belum semua peserta datang ketika pretest dilakukan. Saat sesi ditutup, kebanyakan peserta sibuk dengan anak-anak mereka dan bersiap-siap pulang, sehingga tidak semua peserta mengisi kuesioner posttest dengan lengkap bahkan ada yang tidak mengisi kuesioner sama sekali.

Selain jumlah isian yang tidak sama, perubahan skor yang tidak signifikan juga dapat terjadi karena tidak semua peserta dapat mengisi kuesioner dengan 
cukup fokus. Kebanyakan peserta mengisi kuesioner sambil memangku atau menggendong balitanya yang seringkali bergerak-gerak ingin mengeksplorasi lingkungan, seperti menunjuknunjuk area tertentu sambil memanggil ibunya, merengek, dan sebagainya. Selain itu, pertanyaan mengenai mindful parenting dibuat dalam bentuk isian sehingga hal ini diperkirakan kurang memudahkan bagi peserta yang membawa balita untuk menuangkan pengetahuannya mengenai mindful parenting. Panulis telah menyediakan Kids' Corner yang letaknya di area belakang setting tempat duduk untuk peserta menitipkan anak-anak mereka saat mereka mengikuti kegiatan. Tujuannya adalah agar peserta dapat mengikuti kegiatan tanpa disibukkan dengan balitanya. Namun, tampaknya tidak semua anak dapat dilepas oleh orang tuanya. Mahasiswa yang membantu penulis sebagai fasilitator untuk Kids' Corner juga tidak memadai bila dibandingkan jumlah balita dan luas area yang digunakan untuk Kids' Corner.

Meskipun peningkatan skor pengetahuan mindful parenting tidak signifikan, secara observasi penulis melihat adanya penambahan keterampilan melakukan praktik mindful parenting. Sebelum peserta diberikan latihan mindfulness, peserta tampak sibuk memerhatikan materi dan mengawasi anak bahkan mengarahkan anak agar tetap dalam jangkauan orang tua. Suasana terasa cukup ramai. Ketika pemateri membimbing peserta melakukan latihan mindfulness, suasana terasa sangat hening, anak-anak tetap bermain dalam pengawasan orang tua namun orang tua minim melakukan intevensi. Hal ini juga dibuktikan dengan adanya penurunan dalam skor MAAS yang menunjukkan bahwa peserta lebih mampu menyadari dan memberi perhatian serta berkurangnya sikap penghakiman peserta terhadap persitiwa yang dilalui. Hasil kegiatan ini sesuai dengan penelitian yang dilakukan oleh Dumas, Dishion dkk. (dalam McCaffrey, 2015) dan Duncan dkk. (2009) yang antara lain menunjukkan bahwa pelatihan mindful parenting dapat menurunkan reaktivitas orang tua serta menurunkan stres pengasuhan.

Pelatihan ini hanya diberikan dalam sekali pertemuan dengan rentang waktu efektif sekitar 2,5 jam. Berdasarkan pengamatan penulis, jumlah waktu ini relatif masih ideal untuk sesi pelatihan singkat. Rentang konsentrasi para ibu untuk fokus terhadap kegiatan dapat terganggu apabila dilakukan lebih lama mengingat mereka membawa anak balita. Meskipun pelatihan berlangsung singkat, namun pencapaiannya cukup efektif. Sesi aslinya di Amerika membutuhkan waktu sekitar $7-12$ sesi disertai follow up setelah beberapa bulan untuk menunjukkan hasil yang nyata (Duncan dkk., 2009).

Umpan balik yang penulis dapatkan dari peserta adalah sebagian besar menganggap kegiatan pelatihan ini memuaskan dalam hal kejelasan materi, sikap fasilitator, sarana dan fasilitas, konsumsi, serta metode kegiatan. Sebagian besar juga merasa sangat puas terhadap manfaat yang diberikan dari kegiatan ini. Para peserta memberikan umpan balik untuk melakukan kegiatan dalam setting tempat duduk yang melantai dialaskan matras atau karpet agar leih leluasa dengan anak balita. Peserta juga menyarankan untuk mengadakan kegiatan serupa terutama yang bertemakan tentang mendidik anak sejak dini dan menyadari inner child dalam diri orang tua yang dapat berdampak kepada pola interaksi dengan anak.

\section{KESIMPULAN}

Psikoedukasi dan pelatihan mengenai mindful parenting ini efektif diberikan pada ibu dengn anak balita. Psikoedukasi dan pelatihan ini cukup dapat menambah pengetahuan peserta mengenai mindful parenting serta meningkatkan kemapuan mindfulness orang tua saat berinteraksi dengan anak.

Psikoedukasi dan pelatihan mindful parenting seperti ini dapat diterapkan berkelanjutan pada komunitas-komunitas orang tua yang memiliki anak balita, seperti komunitas orang tua PAUD, POSYANDU, PKK, dan sebagainya.

\section{REFERENSI}

.(2016). Family involvement in early childhood education. Harvard Family Research Project, No. I.

Bower, A. A., \& Casas, J. F. (2016). What Parents Do When Children are Good: Parent Reports of Strategies for Reinforcing Early Childhood Prosocial Behaviors. Journal of Child and Family Studies, 25(4), 1310-1324. https://doi.org/10.1007/s10826-015-0293-5

Brown, A. P., Marquis, A., \& Guiffrida, D. A. (2013). Mindfulness-Based Interventions in Counseling - ProQuest. Journal of Counseling and Development, 91(January), 91(1), 96-104. https://doi.org/10.1002/j.1556-

6676.2013.00077.x

Ciciolla, L., Gerstein, E. D., \& Crnic, K. A. (2014). Reciprocity Among Maternal Distress, Child Behavior, and Parenting: Transactional Processes and Early Childhood Risk. Journal of Clinical Child and Adolescent Psychology, 
$43(5)$,

$751-764$ https://doi.org/10.1080/15374416.2013.812038

Coatsworth, J. D., Duncan, L. G., Nix, R. L., Greenberg, M. T., Gayles, J. G., Bamberger, K. T., ... Demi, M. A. (2015). Integrating mindfulness with parent training: Effects of the mindfulness-en...: EBSCOhost. Developmental Psychology, 51(1), 26-35. Diambil dari http://web.a.ebscohost.com.ezproxy.ub.unimaas .nl/ehost/pdfviewer/pdfviewer?sid=04663da056a2-45ed-886b0db40d4ecd80\%40sessionmgr4002\&vid=0\&hi $\mathrm{d}=4201 \&$ preview $=$ false

Cooklin, A. R., Giallo, R., \& Rose, N. (2012). Parental fatigue and parenting practices during early childhood: An Australian community survey. Child: Care, Health and Development, 38(5), 654-664. https://doi.org/10.1111/j.13652214.2011.01333.x

Crnic, K., \& Low, C. (2002). Everyday stresses in parenting. Handbook of Parenting Volume 5 Practical Issues in Parenting (Vol. 5).

Duncan, L. G., \& Bardacke, N. (2010). Mindfulnessbased childbirth and parenting education: Promoting family mindfulness during the perinatal period. Journal of Child and Family Studies 19(2), 190-202. https://doi.org/10.1007/s10826-009-9313-7

Duncan, L. G., Coatsworth, J. D., \& Greenberg, M. T. (2009). A Model of Mindful Parenting: Implications for Parent-Child Relationships and Prevention Research. Clinical Child and Family
Psychology

Review. https://doi.org/10.1007/s10567-009-0046-3

Hughes, A., Williams, M., Bardacke, N., Duncan, L. G., Dimidjian, S., \& Goodman, S. H. (2009). Mindfulness approaches to childbirth and parenting. British Journal of Midwifery, 17(10), 630-635.

https://doi.org/10.12968/bjom.2009.17.10.4447 0

McCaffrey, S., Reitman, D., \& Black, R. (2017). Mindfulness In Parenting Questionnaire (MIPQ): Development and Validation of a Measure of Mindful Parenting. Mindfulness, 8(1), 232-246. https://doi.org/10.1007/s12671016-0596-7

Setyawan, D. (Mei, 2015). KPAI: Jutaan anak mengalami masalah sosial. http://www.kpai.go.id/berita/kpai-jutaan-anakalami-masalah-sosial/

Snyder, R., Shapiro, S., \& Treleaven, D. (2012). Attachment Theory and Mindfulness. Journal of Child and Family Studies, 21(5), 709-717. https://doi.org/10.1007/s10826-011-9522-8

Taylor, Z. E., Sulik, M. J., Eisenberg, N., Spinrad, T. L., Silva, K. M., Lemery-Chalfant, K., ... Verrelli, B. C. (2014). Development of egoresiliency: Relations to observed parenting and polymorphisms in the serotonin transporter gene during early childhood. Social Development, 23(3), 433-450. https://doi.org/10.1111/sode.12041 